DOI: 10.15393/j9.art.2012.344

\author{
русской литературы и журналистики филологчческого факультета,

\section{ДУХОВНОЕ ЗНАЧЕНИЕ ДОСТОЕВСКОГО В ОЦЕНКЕ И. С. АКСАКОВА И АРХИЕПИСКОПА НИКАНОРА}

Дмитрий Андреевич Кунильский

кандидат филологических наук, доиент кафедрь Петрозаводский государственный университет

(Петрозаводск, Российская Федерация) dkunilsky@mail.ru

\begin{abstract}
Аннотация: В статье представлены два мнения, определяющие христианскую направленность Достоевского и роль этого писателя в жизни русского общества. Первое принадлежит известному славянофилу И. С. Аксакову, второе архиепископу Херсонскому и Одесскому Никанору. Кратко прослежена история взаимоотношений Достоевского и славянофилов: критические отзывы К. С. Аксакова о первых произведениях писателя; претензии Достоевского к славянофилам, высказанные в журнале «Время»; сближение почвенников и славянофилов на Пушкинском празднике в Москве летом 1880 г., проанализированы статья и заметка И. С. Аксакова, посвященные смерти Достоевского, а также письмо Аксакова к О. Ф. Миллеру, где обсуждалось то же горестное событие. Для понимания литературно-критической и идейной позиции Аксакова привлекается написанная им статья-некролог «Несколько слов о Гоголе» (1852 г.), рассмотрены проповеди архиепископа Никанора, в которых говорится о Достоевском и И. Аксакове, подчеркнута общность оценок, данных творчеству Достоевского славянофильским и церковным мыслителями. На основании проповедей архиепископа Никанора сделан вывод о духовной близости Достоевского и славянофильства.

Ключевые слова: славянофилы, творчество Достоевского, отрицательное направление, писатель-христианин, архиепископ Никанор, воцерковленность.
\end{abstract}

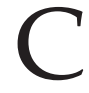

емидесятые годы XIX в. отмечены новой стадией в развитии литературного славянофильства и, в первую очередь, его крупнейшего представителя И. С. Аксакова. Всегда критично смотревшие на русскую литературу, «теперь же славянофилы как бы торжественно усвояли себе Пушкина» $[9,171]$ и других ранее недооцененных отечественных писателей. Важно, что в числе таких новоприобретенных идейных союзников оказался и Достоевский, потенциально близкий славянофилам, но с которым, однако, у них складывались совсем не простые отношения. Понять, что именно в творчестве писателя привлекало Ивана Аксакова и как славянофильская позиция соотносилась с мнением Церкви в лице одного из ее иерархов, - цель настоящей работы. Нелишним будет по этому хотя бы вкратце представить историю контактов Достоевского и Аксакова, рассматривая ее в рамках более общей темы «Достоевский и славянофильство». 
В поле зрения славянофилов Достоевский попал с первых шагов своей литературной деятельности - о появлении «новой звезды» еще в 1845 г. иронично писал родным не кто иной как И. Аксаков $[1,237]$. Опубликованные в 1846 г. дебютные произведения молодого писателя - роман «Бедные люди» и повесть «Двойник» - подверглись суровому разбору в рецензии К. Аксакова, что во многом было обусловлено близостью Достоевского к петербургским западникам и натуральной школе. Некоторые особенности поэтики Достоевского сильно противоречили эстетической системе славянофилов: им претила слишком близкая дистанция между автором и изображаемой действительностью, а также творческий метод писателя, определявшийся как чрезмерный анализ внутренней жизни человека. В представлении страстных почитателей гоголевского творчества, какими были славянофилы, «Бедные люди» (не говоря уже о полностью раскритикованном «Двойнике») во многом уступали произведениям Гоголя, которые объявлялись главным нравственно-эстетическим критерием. Обратившись с начала 1860-х гг. к деятельности публициста, слово взял уже Достоевский, обвинявший славянофилов в отрицании лучших явлений русской литературы и вообще всей послепетровской жизни. Ситуация стала меняться после знакомства с Иваном Аксаковым, состоявшегося, вероятно, в 1863-1864 гг. При всех видимых разногласиях постепенно происходило их взаимное сближение: еще в период издания «Эпохи» (1864-1865) Достоевский считает союзником газету И. Аксакова «День»; в свою очередь, Аксаков приходит к признанию Пушкина вершинным явлением русской литературы, во многом противореча взглядам старших славянофилов.

Возникшее на Пушкинском празднике 1880 г. единство было, по выражению И. Аксакова, «лишь предтечею того великого смятения любви и горя», которое спустя несколько месяцев после торжеств охватило мыслящую часть общества ${ }^{1}$. Речь шла о смерти Достоевского. Аксакову, испытавшему в своей жизни немало горестных утрат, вновь приходилось писать некролог. Но первое впечатление от случившегося выражено в его письме к О. Ф. Миллеру, набросанном в ночь на 29 января 1881 г.:

Горе, горе! Это незаменимая потеря! Теперь из художников писателей и хоронить уже некого. Угасла сила положительная, незаменимая. Он один держал знамя высших нравственных начал. Дело художественного творчества было для него делом души. <..> Это какая-то <пропуск> Божия, которой впрочем мы сто́им. В обществе и литературе у нас царит только одна богема, как выражаются французы. Я совсем сиротею 2 .

Чувства Аксакова легко понять: не являясь друзьями в привычном смысле этого слова, они с Достоевским находили общий язык при обсуждении самых проблемных для обоих тем - таких, как довольно 
сдержанное отношение славянофильского лидера к роману «Братья Карамазовы». Аксаков подбадривал Достоевского в издании «Дневника писателя». Достоевский, в свою очередь, давал советы по организации газеты «Русь». Взаимопомощь была эффективной, что подтверждают строки из письма Достоевского к Аксакову от 28 августа 1880 г.:

Никогда еще в моей жизни я не встречал критика столь искреннего и столь полного участием к моей деятельности как теперь Вы².

Память Достоевского И. Аксаков почтил краткой, но очень эмоциональной заметкой и статьей некрологом в «Руси» ${ }^{4}$. Эти работы, конечно, взаимосвязаны, одна в сжатой форме предвосхищает содержание другой, поэтому для удобства рассмотрим их вместе, привлекая еще один аналогичный текст Аксакова.

Смерть Достоевского, как отмечает Аксаков, вновь сплотила общество и явилась «событием внутренним, нравственного и духовного мира», напомнив о «целой буре восторгов, в приснопамятные дни Пушкинского празднества». Необыкновенное стечение народа на похоронах писателя («Еще никогда никого так не хоронили; ничего подобного не видывал Петербург») ${ }^{5}$ поставила перед славянофильским автором вопрос о причинах огромной популярности Достоевского, шедшего часто наперекор модным общественным тенденциям. Достоевский не был ни западником, ни либералом, ни материалистом или позитивистом; в его сочинениях нет столь соблазнительной критики существующего государственного порядка, «художественной проповеди отрицания». Напротив, «не процессом мертвящего отрицания» говорит Аксаков о Достоевском, «но преизбытком любви, жизненною силою верующего духа, торжеством нравственной правды в сердцах человеческих учил он превозмогать неправду внешних явлений» ${ }^{6}$.

Итак, для Аксакова крайне важно, что Достоевский, в отличие от писателей отрицательного направления ${ }^{7}$, которые ставят перед собой задачу вызвать, «вместе с участием к социальной обстановке воспроизведенных лиц, негодование и бунт в душе читателя», преследовал совсем другую цель. «Идея внешней, социальной равноправности бледнела и исчезала для него в высщей идее - в христианской идее 6 ратства» ${ }^{8}$. Другими словами, Достоевский как настоящий христианин умел «в каждом признать человека, опознать брата и Бога», что стало отличительной чертой его художественного и публицистического творчества. При сходной тематике, сочувствии к «униженным и оскорбленным», проявлявшемся как со стороны Достоевского, так и со стороны отрицателей, у неискушенного в литературных делах человека могло возникнуть впечатление, что почивший романист был близок к радикальному 
крылу русской интеллигенции. Вот почему И. Аксаков так обстоятельно поясняет разницу между Достоевским и отрицательным направлением:

Достоевский умер! Потеря незаменимая! В нашей современной литературе это была сила, не растлевающая, не разрушающая, а укрепляющая и зиждительная. Это был мощный талант и замечательный мыслитель 9.

По словам Аксакова, русская общественность отдала должное именно «писателю-мистику: бесстрашному (ибо в наши дни нужно для сего мужество), непостыдному исповеднику имени Господня... <..> Это не был ни литератор-виртуоз, ни доктринер или теоретик, - это был христианин, исполненный живой, действенной веры, послуживший данным ему талантом Христову делу до самой смерти...» 10

В подтверждение своих мыслей Иван Аксаков обильно цитирует «Дневник писателя», но, по большому счету, не касается романов Достоевского, исключая самую общую характеристику его художественного миросозерцания. Такая постановка вопроса в общем-то отличала Аксакова критика ${ }^{11}$, хотя вспомним его замечательные работы о Пушкине и Тютчеве, где предлагается настоящий филологический анализ произведений названных авторов. Вероятно, Аксакову все-таки была ближе публицистика Достоевского, нежели его художественное творчество, но с одной оговоркой: эта публицистика принадлежала автору великих романов, о чем славянофильский лидер обмолвился в письме в связи с Пушкинской речью Достоевского:

Он... (Достоевский. - Д. К.) прочел мастерски, такую превосходную, оригинальную вещь, еще шире и глубже захватывающую вопрос о народности, чем моя статья, причем не в форме логического изложения, а в живых, реальных образах, с искусством романиста, и впечатление было поистине потрясающее. Я никогда ничего подобного не видел ${ }^{12}$.

И еще один важный момент. Обращает на себя внимание явное сходство этих работ Аксакова и ранней его статьи «Несколько слов о Гоголе» («Московский сборник». 1852). Все они написаны, когда земной путь писателей завершился и необходимо было подвести первые итоги. Автор надеется, что скорбные, отрицательные по своему характеру события станут потрясением для русского общества и направят его жизнь в верное русло. Концовки статей почти одинаковы. Сравним:

Теперь, не досказав своего слова, похищен смертью человек на которого так долго обращались взоры, полные надежд и ожидания, который был последнею современною светлою точкою на нашем грустном небе... Содрогнется ли, хоть теперь, ветреное племя?.. [2, 252] («Несколько слов о Гоголе», 1852). 
Кумиры настоящего времени, учители отрицания забудутся или займут приличное себе место в исторических архивах, а наследие, оставляемое Достоевским, еще ожидает достойных наследников в грядущих поколениях. Он любил, он верил в русскую молодежь... Обманется ли его надежда и вера?.. ${ }^{13}$ («По поводу смерти Достоевского», 1881).

Мысль Аксакова можно раскрыть через любимые Достоевским стихи из Евангелия от Иоанна:

Истинно, истинно говорю вам: если пшеничное зерно, падши в землю, не умрет, то останется одно; а если умрет, то принесет много плода (Ин. 12:24) ${ }^{\mathbf{1 4}}$.

Художественные создания, глубоко трогающие читателей, вызывающие у них чувство неподдельного восхищения, не прошли бесследно для великих писателей. «Пусть представят они себе, - говорит И. Аксаков о поклонниках Гоголя, - этот страшный, мучительный процесс творчества, прелагавший слезы в смех, и лирический жар любви и той высокой мысли, во имя которой трудился он, - в спокойное, юмористическое созерцание и изображение жизни. Человеческий организм, в котором вмещалась эта лаборатория духа, должен был неминуемо скоро истощиться...» $[2,251]$ Та же мысль видна и в оценке романов Достоевского, которые, по заключению Аксакова, «писались плотью и кровью, - на каждую строку изводилась жизнь самого автора: болезненный процесс творчества, преждевременно унесший его в могилу!» ${ }^{15}$. Неслучайна потому и гоголевская реминисценция, возникающая в некрологе Достоевскому:

Талант его не слабел, но, казалось, только теперь достиг настоящего блеска и зрелости. Еще много вправе мы были ожидать от него... Старые силы, старые дарования сходят со сцены. Кто же является им на смену?.. Нет ответа!.. ${ }^{16}$

Почти три десятилетия назад Аксаков определил значение Гоголя для России как более важное, чем Пушкина, Грибоедова и Лермонтова. «Явится ли еще подобный художник или, быть может, со смертью Гоголя, наступает для нас иная пора?..» $[2,252]-$ риторически спрашивал публицист. Несомненно, памятны были Аксакову прозвучавшие в «Выбранных местах из переписки с друзьями» слова Гоголя:

Нет, не Пушкин и никто другой должен стать теперь в образец нам: другие уже времена пришли. <..> Христианским, высшим воспитаньем должен воспитаться теперь поэт ${ }^{17}$.

Аксаков в своей статье 1852 г. имел в виду, что это требование Гоголя к поэту осуществил сам Гоголь. А сходство направленности, стиля, формулировок в некрологах Гоголю и Достоевскому позволяет сделать вывод, что теперь таким писателем-христианином для И. Аксакова стал Достоевский. 
В параллель к этой оценке творчества Достоевского интересно привести мнение известного церковного автора, архиепископа Никанора, среди разнообразных литературных трудов которого есть и проповедь, посвященная кончине самого Ивана Аксакова.

Архиепископ Никанор, в миру Александр Иванович Бровкович, родился в 1827 г., окончил Санкт-Петербургскую духовную академию, после чего какое-то время преподавал там; занимал пост ректора в нескольких духовных семинариях и в Казанской духовной академии, где получил степень доктора богословия; служил викарием Донской епархии, епископом Уфимским, и в 1886 г. возведен в сан архиепископа Херсонского и Одесского. Умер в Одессе в 1890 г. Он, как свидетельствует В. В. Зеньковский, «был чрезвычайно широко и разносторонне образован, много и очень тщательно работал научно... следил очень пристально за всеми проявлениями современной культуры...» $[4,89]$ Перу архиепископа Никанора принадлежит трехтомный труд «Позитивная философия и сверхчувственное бытие» (СПб., 1875-1888), в котором сказались недюжинные философские способности автора, отмеченные крупными мыслителями рубежа веков (см: [7, 296-297], [6, 117-120]).

Русскую общественную жизнь и литературу архиепископ Никанор рассматривает в своих проповедях сквозь призму библейских событий, считая символичным, что поминовение Достоевского, и позднее И. Аксакова, календарно совпало с Неделей о блудном сыне $^{18}$. Евангельская притча кажется проповеднику хорошо приложимой к любой эпохе:

Она имеет мировое значение, начинаясь и постоянно повторяясь на земле, от начала бытия, продолжаясь и оканчиваясь на небе и имея завершиться там же на небе только с концом сего привременного земного бытия ${ }^{19}$.

Собственно, «все люди, более или менее стремящиеся ко спасению», как полагает архиепископ Никанор, «проходят свою жизнь по образу двух сынов Отца небесного: старшего добропорядочного, но жесткого, и младшего распутного, но мягкосердого» (С. 229). Достоевский и И. Аксаков напоминают автору поучений сына младшего: оба не раз ошибались в своей жизни, оба завершили земной путь как христиане. Так, Достоевский, «который прошел... все ступени до мысленного шатания и нравственного блуждания, до отрицания и преступления, до самых тяжких жизненных испытаний, даже до каторги», по словам архиепископа Никанора, «затем стал не только достойнейшим и полезнейшим сыном отечества, но и обновленным сыном Отца небесного» (С. 220-221). При этом если в биографии великого писателя традиционно выделяется один ключевой момент, повлекший за собой изменение его взглядов, 
то Аксаков, по мнению архиепископа Никанора, временами сбивался с правильной дороги, хотя это проявлялось, конечно, не так сильно, как в случае с Достоевским:

...Его (т. е. Аксакова. - Д. К.) мощный, но замечтавшийся, самодумный дух, в гордыне своей исключительности, в ревности о своеобразно понимаемом благе народа не всегда по разуму Божию, - его мощный дух впадал и в заблуждения нелегкие, и в антипатии тяжкие и неправые, и в обличения беспредельно хульные, отстаивая долго и упорно своим пером и словом то и другое вслух всего света... (С. 228).

Поступая таким образом, славянофильский лидер невольно сближался с теми из своих оппонентов, кто, как замечает церковный автор, «отрицают правосудие Божие», немилосердно обличая пороки современной русской жизни (вот что, к примеру, говорит архиепископ Никанор о таких «обличителях»:

...это злоязычники, которых в мире было всегда много, которые сперва работали только языками, а теперь стали работать и перьями, и печатью, да и всякими способами (С. 220).

Интересно, что подобные упреки ранее адресовал славянофилам Достоевский, полагавший, что в своем отрицании сложившегося миропорядка славянофилы оказывались недалеки от самых радикальных теоретиков западнического толка. Осуждение архиепископа Никанора вызвано также тем, что искренне любивший православную веру Аксаков «представлял ее шире и мелководнее, чем следует, равняя в своем сердце русского нововера или старовера, равно и все оттенки как нововерия, так и староверия русского...» (С. 228).

Названные уклонения, однако, не помешали И. Аксакову провести свои дни в «неуклонном... и неустанном ратоборстве за русскую веру, как за веру русского народа» (С. 227), а Достоевскому «употребить свой высокий дар на служение идеалу добра... в своей предсмертной исповеди признать себя рабом Христовым, а Христа провозгласить светом мира, и в частности светом Христолюбивого нашего отечества...» (С. 221). В понимании церковного автора очень важным оказывалось то обстоятельство, что, отстаивая христианские идеалы, Достоевский и И. Аксаков часто шли против течения, не боялись всенародно исповедовать свои религиозные убеждения. Достоевский, по словам архиепископа Никанора, это делал «на самом трудном и высоком поприще умственного творчества» (С. 221), И. Аксаков «подвизался за истину на открытом публицистическом поприще» (С. 225).

То одобрение, с которым проповедник говорит о Достоевском, становится ощутимее, если привести характеристики, данные архиепископом Никанором Пушкину и Гоголю. 
Имели мы Пушкина, который во многом был не христианский мыслитель и поэт, который воспевал только страсти и страсти, у которого бывали только минутные проблески обращения к духовной природе человека и к небу, да и то не называя Бога даже по имени; который умер однако же христианином после известного предосудительного злоключения. Имели Гоголя, который был реальным изобразителем сколько высокой поэзии человеческого, как только человеческого, а не христианского сердца, столько же и величайшей его грязи, который обратился к христианству, когда уже пошатнулся душевными силами... (С. 221).

По сравнению с ними Достоевский сознательно и твердо проповедовал евангельские истины, направляя все силы на «глубоко художественное... разъяснение притчи Спасителя о блудном сыне, на создание многих трогательнейших образов блудных сынов и дщерей из среды нашего русского современного общества» (С. 221).

Журнальная деятельность И. Аксакова представляется архиепископу Никанору борьбой за русскую веру, а сам Аксаков выглядит как «ратоборец... как исполин среди пигмеев, как русский богатырь среди вражеской стаи, как дальнозоркий государственный ум, даже как исповедник и защитник веры, так как в его положении, в замкнутом круге интеллигентной среды, среды иногда не только неверной, но нередко и враждебной вере, ратовать за веру значило прать не против рожна, а против тысячи рожнов» (С. 227-228).

В заключение своих проповедей архиепископ Никанор призывает помолиться о только что почивших рабах Христовых: Федоре Достоевском, «нашем достохвальном и приснопамятном учителе», и Иване Аксакове, непоколебимом защитнике православных христиан. Оценки, которыми мирянин Аксаков удостоил автора «Дневника писателя», в значительной степени совпадают с позицией ученого-богослова, имевшего возможность судить о воцерковленности этих ли тераторов со знанием дела ${ }^{20}$. Оба - и славянофильский писатель и церковный проповедник - отмечают в Достоевском способность идти своим, христианским, путем, даже в самых неблагоприятных для этого социально исторических обстоятельствах. И не просто идти, а еще и увлекать за собой огромные массы людей, которые могли бы выбрать совсем иную дорогу.

Кроме того, мнение архиепископа Никанора как человека непредвзятого является важным свидетельством близости Достоевского к славянофильству, причем близости духовной, смещающей все расхождения в литературных и общественных взглядах на второй план.

\section{Примечания}

Работа выполнена при финансовой поддержке Программы стратегического развития ПетрГУ на 2012-2016 гг. в рамках реализации комплекса мероприятий по развитию научно-исследовательской деятельности. 
Аксаков И. С. Сочинения. СПб., 1886. Т. 2. С. 487.

2 РГБ. Ф. 93. ІІ. Карт. 1. Ед. хр. 23. Л. 16-16 об. Опубликовано с неточностями в кн.: Литературное наследство. М., 1973. Т. 86. С. 532-533.

3 Достоевский Ф. М. Полн. собр. соч.: В 30 т. Л., 1988. Т. ХХХ / 1. С. 213-214.

41 февраля 1881 г., в день похорон Достоевского, И. Аксаков присутствует на заказанной по случаю смерти писателя панихиде в церкви Успения на Овражках, в Москве (Летопись жизни и творчества Ф. М. Достоевского: В 3 т. СПб., 1999. Т. 3. С. 562).

5 Аксаков И. С. Сочинения. Т. 2. 487.

6 Там же. С. 489.

7 В 1840 - 1850-х гг. «отрицательным направлением» принято было называть натуральную школу, по поводу которой с Белинским полемизировали славянофилы. Позднее этот термин распространялся на многих писателей и критиков, вскрывавших общественные «язвы» и пытавшихся расшатать привычный миропорядок. В противоположность отрицателям славянофилы выдвигали концепцию положительного направления, основанную на национальных ценностях и идеалах христианской религии.

8 Аксаков И. С. Сочинения. Т. 2. С. 490.

9 Русь. 1881. 31 янв. № 12. С. 3.

10 Аксаков И. С. Сочинения. Т. 2. С. 491, 492.

11 Ср. с наблюдением дореволюционного исследователя о характере литературно-критических работ Аксакова: «Критик не столько разбирает литературные достоинства писателей самих по себе, сколько отыскивает в их творчестве, с точки зрения славянофильства, народные, чисто русские стихии» [8, 24].

12 Письмо И. С. Аксакова о Московских праздниках по поводу открытия памятника Пушкину // Русский архив. 1891. Кн. 2. № 5. С. 96.

13 Аксаков И. С. Сочинения. Т. 2. С. 494.

14 Об отношении Достоевского к Евангелию от Иоанна см.: [3, 337-348].

15 Русь. 1881. 31 янв. № 12. С. 3.

16 Там же.

17 Гоголь Н. В. Полн. собр. соч. [М.; Л.]: Изд-во АН СССР, 1952. Т. 8. С. 407-408.

18 Неделей о блудном сыне называется третья неделя до Великого поста. В это время принято вспоминать названный евангельский сюжет, готовиться к длительной молитве и покаянию. Напомню, что Достоевский умер 28 января (по новому стилю - 9 февраля) 1881 г., И. Аксаков - 27 января (по новому стилю - 8 февраля) 1886 г.

19 Никанор, архиепископ Херсонский и Одесский. Поучения, беседы, речи, воззвания и послания. 3-е изд. в новом составе. Т. 1. Одесса, 1890. С. 213. В дальнейшем ссылки на это издание даны в скобках с указанием страницы. 20 Еще одним подтверждением, что в сознании представителей Церкви эти имена объединялись, служит высказывание духовника И. Аксакова прот. А. М. Иванцова-Платонова, также прозвучавшее в связи с кончиной славянофильского публициста: «Кто заменит в литературной деятельности Ивана Сергеевича Аксакова?.. Кто заменит его в особенности у того знамени, под которым непоколебимо и неуклонно работал он около сорока лет, сначала с своими достопамятными учителями и друзьями: Хомяковым, Киреевским, Юрием Самариным, братом по плоти и духу Константином Аксаковым, к которому и в последующие годы по временам примыкали сильные люди, - даровитейший и влиятельнейший писатель Ф. М. Достоевский, народный герой Скобелев... серьезный мыслитель и ученый Н. Я. Данилевский...» $[5,54]$. 


\section{Список литературы}

1. Аксаков И. С. Письма к родным. 1844-1849. М.: Наука, 1988. 704 с.

2. Аксаков К. С., Аксаков И. С. Литературная критика. М.: Современник, 1982. $383 \mathrm{c}$.

3. Дудкин В. В. Достоевский и Евангелие от Иоанна // Проблемы исторической поэтики. Петрозаводск: ПетрГУ, 1998. Вып. 5: Евангельский текст в русской литературе XVIII-XX веков: цитата, реминисценция, мотив, сюжет, жанр. Вып. 2. С. 337-348.

4. Зеньковский В. В. История русской философии: в 2 т. Л.: Изд-во Эго, 1991.

5. Иваниов-Платонов А. М., прот. За третье десятилетие священства (18831893). Слова, речи и некоторые статьи заслуженного проф. Моск. ун-та прот. А. М. Иванцова-Платонова. Сергиев Посад: 2-я типография А. И. Снегиревой, 1894. 238 с.

6. Кунильский А. Е. «Лик земной и вечная истина». О восприятии мира и изображении героя в произведениях Ф. М. Достоевского. Петрозаводск: ПетрГУ, 2006. $304 \mathrm{c}$.

7. Кучерская М. А. Никанор // Русские писатели. 1800-1917. М.: Большая Российская энциклопедия, 1999. Т. 4. С. 296-297.

8. Лобов Л. Славянофилы как литературные критики // Известия Санкт-Петербургского славянского благотворительного общества. 1904. № 8. С. 7-29.

9. Страхов Н. Н. Литературная критика. М.: Современник, 1984. 431 с.

\section{Dmitriy Andreevich Kunil'skiy}

PhD in Philology, Associate Professor, Department of Russian Literature and Journalism, Faculty of Philology, Petrozavodsk State University

(Petrozavodsk, Russian Federation) dkunilsky@mail.ru

\section{THE SPIRITUAL SIGNIFICANCE OF DOSTOEVSKY AS EVALUATED BY I. S. AKSAKOV AND ARCHBISHOP NIKANOR}

\footnotetext{
Abstract: Our article is an analysis of two opinions on the Christian meaning of Dostoevsky and his role for Russian society. One of the opinions was voiced by the famous Slavophile I. S. Aksakov, the other by Nikanor, Archbishop of Kherson and Odessa. We provide a brief overview of Dostoevsky's relations with the Slavophiles, including K. S. Aksakov's critical reviews of his earliest works, Dostoevsky's criticism of Slavophiles in Vremya, the convergence between the pochvenniki and Slavophiles at the Pushkin celebration in Moscow in summer 1880. We have analysed I. S. Aksakov's article and short note on the death of Dostoevsky, as well as the Slavophile's letter to O. F. Miller discussing the sad event. To correctly understand Aksakov's critical stance and ideological position we must turn to the obituary he published under the title Several words on Gogol (1852). We also focus on Archbishop Nikanor's sermons where he mentions Dostoevsky and I. Aksakov, emphasizing the similar assessment of Dostoevsky by both thinkers. The Archbishop's sermons prove the spiritual affinity between Dostoevsky and the Slavophile thought.

Keywords: slavophiles, Dostoevsky's works, negative direction, Christian author, Archbishop Nikanor, 'churching'
} 


\section{References}

1. Aksakov I. S. Pis'ma k rodnym. 1844-1849 [Letters to Relatives. 1844-1849]. Moscow, Nauka Publ., 1988. 704 p.

2. Aksakov K. S., Aksakov I. S. Literaturnaya kritika [Literary Criticism]. Moscow, Sovremennik Publ., 1982. 383 p.

3. Dudkin V. V. Dostoevskiy i Evangelie ot Ioanna [Dostoyevsky and The Gospel of John]. Problemy istoricheskoy poetiki [The Problems of Historical Poetics]. Petrozavodsk, Petrozavodsk State University Publ., 1998. Vol. 5: Evangel'skiy tekst v russkoy literature XVIII-XX vekov: tsitata, reministsentsiya, motiv, syuzhet, zhanr [The Gospel Text in Russian Literature of 18th-20th Centuries: Quotation, Reminiscence, Motif, Plot, Genre]. Issue 2, pp. 337-348.

4. Zen'kovskiy V. V. Istoriya russkoy filosofii: $v 2$ tomakh [The History of Russian Philosophy: in 2 Vols.]. Leningrad, Ego Publ., 1991.

5. Ivantsov-Platonov A. M. Za tret'e desyatiletie svyashchenstva (1883-1893). Slova, rechi i nekotorye stat'i zasluzhennogo professora Moskovskogo universiteta prot. A. M. Ivantsova-Platonova [The Third Decade of the Priesthood (1883-1993). Adresses, Speeches and Some Articles by the Honorary Professor of Moscow University, archpriest A. M. Ivantsov-Platonov]. Sergiev Posad, 2-ya tipografiya A. I. Snegirevoy Publ., 1894. 238 p.

6. Kunil'skiy A. E. "Lik zemnoy $i$ vechnaya istina». O vospriyatii mira $i$ izobrazhenii geroya v proizvedeniyakh F. M. Dostoevskogo ["The Face of the Earth and the Eternal Truth". On the Perception of the World and the Representation of Hero in the Works by Fyodor Dostoyevsky]. Petrozavodsk, Petrozavodsk State University Publ., 2006. 304 p.

7. Kucherskaya M. A. Nikanor [Nikanor]. Russkie pisateli. 1800-1917 [Russian Writers. 1800-1917: Biographical Dictionary]. Moscow, Great Russian encyclopedia, 1999, vol. 4, pp. 296-297.

8. Lobov L. Slavyanofily kak literaturnye kritiki [Slavophiles as Literary Critics]. Izvestiya Sankt-Peterburgskogo slavyanskogo blagotvoritel'nogo obshchestva [Proceedings of the St. Petersburg Slavic Benevolent Society], 1904, no. 8, pp. 7-29.

9. Strakhov N. N. Literaturnaya kritika [Literary Criticism]. Moscow, Sovremennik Publ., 1984. 431 p. 